
\title{
$\begin{array}{ll}\text { Research Square } & \begin{array}{l}\text { Preprints are preliminary reports that have not undergone peer review. } \\ \text { They should not be considered conclusive, used to inform clinical practice, } \\ \text { or referenced by the media as validated information. }\end{array}\end{array}$
}

\section{A Cost Model for PV Based Renewable Energy Projects}

\section{Marwa Ibrahim ( $\nabla$ yara_mh2003@yahoo.com )}

Mechanical Engineering Department, Engineering research Division, National Research Centre (NRC) 12622, Egypt

\author{
M. elbayoumi \\ National Research Centre
}

\section{Research Article}

Keywords: Renewable Energy, PV Solar System, Feasibility Study, Estimation Cost, Cost Analysis, Risk Cost, Direct/ Indirect Cost and Project Success factors

Posted Date: December 18th, 2020

DOl: https://doi.org/10.21203/rs.3.rs-128963/v1

License: (c) (i) This work is licensed under a Creative Commons Attribution 4.0 International License. Read Full License 


\title{
A COST MODEL FOR PV Based RENEWABLE ENERGY PROJECTS
}

\author{
M.A. El Bayoumi ${ }^{1}$ and Marwa M. Ibrahim ${ }^{1}$
}

${ }^{1}$ Mechanical Engineering Department, Engineering research Division, National Research Centre (NRC) 12622, Egypt

\begin{abstract}
The energy from renewable sources had always been perceived as free or at least lower cost energy, with its sourcing from natural sources such as solar radiation and wind energy. In actual the cost breakdown of renewable energy would exceed that of traditional energy sources in almost all cases. This study attempts to produce a cost model for renewable energy systems. The model takes into account different requirements and site variations into account. In this paper; elements of cost model Renewable Energy System (RES) especially photo-voltaic solar systems has been investigated. Cost items are presented alongside a to-do checklist for new PhotoVoltaic (PV) solar energy system. The goal of this study is to construct a model that would cover the cost sources as well as bring into attention the unexpected sources of cost variations that includes all possible cost items of new solar renewable energy system. The feasibility of the new system is expressed in terms of Total Cost (T.C) and Cost of Energy (COE). The model can evaluate feasibility of off-grid as well as on-grid systems. The model investigated properly as well as an empirical analysis and verified through results comparison with reviewed case studies. The results revealed that cost of off-grid systems are higher than cost of on-grid systems due to cost of batteries as well as cost of standby generators. So, it would be more feasible to use offgrid system only in remote or isolated area. Risk Cost lists, ranking and successful factors of new renewable project are exhibited.
\end{abstract}

Keywords: Renewable Energy; PV Solar System; Feasibility Study; Estimation Cost; Cost Analysis; Risk Cost; Direct/ Indirect Cost and Project Success factors

\begin{tabular}{lc} 
Abbreviations: & \\
\hline Cash Flow Diagram & CFD \\
Cost of Energy & COE \\
Critical Successul Factors & CSF \\
Executive \& Operation Cost & $\mathrm{K}$ \\
Interest Rate & $\mathrm{IR}$ \\
Levelized Cost of Energy & LCOE \\
Measure-Correlate-Predict & $\mathrm{MCP}$ \\
Other Project Cost & OEC \\
Others Cost & $\mathrm{L}$ \\
Photo-Voltaic & $\mathrm{PV}$ \\
Planning Cost & $\mathrm{Y}$ \\
Purchasing Cost & $\mathrm{Z}$ \\
Renewable Energy System & $\mathrm{RES}$ \\
Study Cost & $\mathrm{X}$ \\
Time & $\mathrm{Ti}$ \\
Total Cost of Photo-Voltaic System & TCPVS \\
Actual Cost & AC \\
Additional Cost & ADC \\
\hline
\end{tabular}




\section{INTRODUCTION}

Historically, the production of renewable energy resources has faced a range of challenges, particularly in relation to prices, legislation and financing. With the recent sustained cost growth and related fossil fuel market volatility, investors have become more drawn to renewable energy generating economies. Previously it has implemented market-driven incentives and approaches. Traditionally, market-based incentives and strategies have been suggested as options for growing investment in renewable energy sources. Both approaches are aimed at reducing the levelized generation cost to cover the gap between renewable energy and grid electricity rates, and at providing sufficient returns for external donors to provide project funding. Nevertheless, policy uncertainties for developers and investors have hindered investment in renewable energy, including timelines, funding levels, support period and sustainability.

Although many incentive mechanisms and renewable energy policies have been introduced to encourage investment in renewable energy, such as feed-in tariffs and tax credits, investment in renewable energy often requires enormous initial capital costs and entails many uncertainties. Renewable energy projects are delayed unless the issues are well addressed. Recently, a boom in project funding could be seen in technologies as onshore wind and solar for smaller complexes, moderately small and low-risk projects as shown in section 2 of the troubles caused by undervaluation.

Both stakeholders in renewable energy projects need to have a good understanding of the value and intentions of project funding in low risk environments. Policymakers trying to implement policies that encourage private investment in renewable energy technology, project promoters and financial intermediaries thinking about how to advance energy generation financing, and policy analysts making investment decisions for power plants in the transition to low-carbon energy systems [1]: This paper therefore investigates / addresses the following questions:

- Importance of funding in developed, low-risk countries for renewable energy projects.

- The drivers and underlying reasons for using project funding in these environments.

This work provides a rational economic study for project financing in general, as well as an empirical analysis of on-site project financing, a site with a relatively low-risk environment for renewable energy, as well as substantial investment in both conventional and renewable power generation over the past few years. To our knowledge, economic research has not been rigorously analyzing the drivers of project funding in today's energy projects in investment-grade countries. The purpose of the current study is to create a model that would cover the cost sources as well as bring to attention the unexpected sources of cost fluctuations and to do checklist of general costs of the new solar renewable energy system.

The rest of paper illustrates as following: Section 2 presents the topic of this paper, discusses the literature on history and suggests the steps taken in the study to be explained. Section 3 is usually devoted to the Different cost models. Section 4 describes the methodology to collect the financial elements of renewable energy cost. Section 5 investigated equation of total cost of renewable energy project in general. Section 6 concluded risk types and successful factors for renewable energy project. Conclusions are presented in section 7. 


\section{REVIEW OF THE DRAWBACKS OF COST UNDERESTIMATION}

Cost studies of renewable energy systems have proven to be the main obstacle to the deployment of RES. Steffen [2], [3] assessed the value of project financing in investment-grade countries for renewable energy projects, underlying drivers of using this kind of funding. Eight potential reasons for project financing; such as: pollution risk, debt overhang, securitization and agency disputes between project owners and contracting parties were identified. Results show that project financing has far greater importance for renewable energy systems in extreme cases with particularly low investment risks. Implications for policy-makers and the financial sector as well as energy scholars concerned with investment decisions in power generation were discussed.

In another study [4], [5] a new funding instrument; called the hybrid bond, was introduced to develop renewable energy projects. The hybrid bond is a portfolio of projects related to renewable energy. It not only covers the initial capital costs financially but also handles the risks associated with investing in renewable energy. Core risks were identified including industry, credit, liquidity, operational and political risks. The proposed structure revealed that hybrid bonds would fund a substantial portion of renewable energy projects ' upfront capital costs and are capable of managing significant uncertainties.

Business and credit risks can easily be quantified and hedged while liquidity, operational and political risks are unlikely to be feasible. The break-even point of a renewable energy project also requires a long time horizon, where a secondary market rarely exists [6], [7]. Trading an initiative for renewable energies is difficult to create extremely illiquid investments, thereby increasing the risk of deflation.

During the last decade, investor perceptions of risk and return have become an important source of research in energy policy and energy economics literature [8]. This had led to the evolving research trend addressing gaps for large renewable energy projects between utilities and institutional investors. For example, [9] examined whether higher utility capital costs relative to institutional investors could explain why, under the German feed-in tariff, utilities were not in a rush to invest in low-risk, low-return renewable energy projects such as solar photovoltaics. A subsequent segmentation analysis showed that two groups of potential renewable energy group investors may be identified with different risk-return expectations: "local patriot" and "yield investors" [10]. By contrast to professional investors, a majority of retail investors follow simple decision laws, such as calculating payback time or depending on their personal experience when making the investment.

Implementation of energy projects is tied to country-specific risks. In Africa perceived and actual investment risks are greater than in developed countries. Investors are therefore looking for a higher rate of return to accommodate those risks [11]. The challenge of attracting adequate and affordable financing is a crucial obstacle to the deployment of RE technologies in Africa. Sweerts et al [12] presented comparison of the effect of financial conditions on the cost of generating electricity through six renewable energies and three fossil technologies in 46 African countries. The results showed significant cost differences and demonstrated the degree to which current financial practices put renewable at a disadvantage. The TIAM-ECN energy-economy climate model was used to demonstrate how a much higher deployment of RES results in 
lowering financing costs. The results showed that improvements in the funding systems could overshadow the effect of learning technology. Consequently, financial de-risking is a crucial ingredient for exploiting Africa's renewable energy potential.

Ketterer [13], [14] investigated if structured exchange-traded products are viable instruments for hedging the risk of renewable energy. The researcher found such an assessment to be difficult for at least two reasons: First, the rapid increase in renewable generation has significantly changed the characteristics of wholesale electricity prices. Second, recent changes to the subsidy system to pay for the production of renewable electricity have altered the current fixed price structure with a view to more market-oriented payments. An extra study examined how much risk renewable energy producers would hedge with exchange-traded derivatives through financial risk transfer [15]. Proposed electricity price model, which is capable of taking into account the distinct effect of weather-dependent renewable generation and the spatial distribution of renewable generation capacities [16].

The rising share of renewable energy coupled with its intermittent existence poses significant new challenges for power market participants. The management of the related stochastic output and political risks was viewed in the view of a proprietor of such a physical renewable energy asset [17]. Dealing with political risk has long been a daunting challenge in the valuation of international investment because of two distinct reasons: firstly, it is not easy to quantify political risk; and secondly, it is difficult to incorporate existing political risk ratings into a quantitative investment study, since most of them use subjective expert assessments [18], [19]. The explanation is that they are heuristics-based, and the decision-maker should use them to compensate for political risk through an upward adjustment to discount rate.

Gatzert et al., [20] It has shown that, apart from insurance, diversification is, in particular, one of the most important tools for managing the risk of wind energy projects and is being used in different dimensions, due to a lack of alternative cover. Their work aimed to address detailed emerging risks and approaches to risk management for renewable energy projects identifying significant differences in risk transfer, thus distinguishing onshore and offshore wind parks with a European market focus. Furthermore, policy and regulatory uncertainties tend to be a major barrier to investments in renewable energy while at the same time insurance coverage or alternative risk mitigation is severely restricted [21], [22]. This demonstrates the need for new risk management strategies to ensure sustainable production of renewable energies.

Solar resource estimation risk is also one of the major solar photovoltaic project risks that affect the decision of the lender to provide financing and to assess capital costs [23]. There have emerged a number of measures to minimize the risk. Multiple data sources are used by the best practice in resource estimation through the measure-correlate-predict (MCP) technique as compared to standard practice that relies solely on modeled data source. The best practice case could also handle higher debt ratios and have lower electricity costs (LCOE) while the standard practice case would need lower debt ratios but a higher LCOE.

Liua and Zeng have analyzed investment risk in renewable energy using system dynamics approach [24]. In the first part of the work three key risks were addressed during renewable energy investment, technical, political, and market risks. Monte Carlo Simulation was used to 
quantify the probability of investments in renewable energy. Integrating a variety of risk assessment methods has established the relative degree of difference of the blurred risk assessment model based on variable weight interval in [25], [26]. The outcome of the numerical example revealed that the major factor affecting the investment in the early stage of development was political risk and technical risk; market risk steadily became the main uncertainty affecting the investment in the mature stage of development.

As a result, a large number of renewable energy projects are being carried out worldwide, facing numerous challenges and barriers that result in failure for many of the recent projects. Although several programs to promote renewable energy production have been initiated by governments in response, these efforts are limited to supporting renewable energy use. Maqbool [27] Systematic analysis of critical success factors (CSFs) influencing renewable energy projects was discussed. A total of 41 significant success factors (SSFs) for renewable energy projects in Pakistan were identified through a systematic process, which are further extracted into 5 critical success factors. Finally, a novel causal model is set up to illustrate the mechanisms of interaction to ensure the success of SSFs and CSFs in renewable energy projects. The results show that environmental factors are the predominant CSFs with the highest correlation that show the significant effect over the success of a project.

\section{DIFFERENT COST MODELS}

Several attempts have been made to produce cost models for general systems not renewable energy systems specially. However different models has different short comes. Various studies investigated general project cost models [28], [29] identified total project costs are classified as all project-specific costs incurred during the establishment but prior to the operation of the facility as following:

$$
\text { Actual Cost }(\mathrm{AC})+\text { Additional Cost }(\mathrm{ADC})=\text { Total Project cost }(\mathrm{TPC})
$$

a) Actual Cost (AC) shall be defined as all engineering design costs (after conceptual design), facilities construction costs and other costs specifically related to those construction efforts. AC may include, but not limited to: project and construction management during design, construction management and planning reporting; contingency and economic acceleration of the AC-applied elements; research and development during design, construction management and reporting; contract support directly related to design, construction; equipment and renovation equipment.

b) Additional Cost ADC is defined as any other project costs not included in the AC, such as research \& development support, during the-authorization costs prior to the start of design, plant support costs during construction, activation and start-up. ADC shall include, but not limited to: research and development; documentation; project data sheets; brief project report sheets; sit-in survey; schematic design plan; and provide for evaluation of requirements.

c) (C) Total Project Cost TPC shall be defined as all project-specific costs incurred through the creation of the facility but prior to its service. It is composed of both $\mathrm{AC}$ and ADC costs. TPC will include, but not limited to, tasks such as: design and construction, contingency, economic escalation, feasibility studies reports, maintenance procedures (support facilitation), one-time start-up costs, initial operator planning and start-up costs. 
Hendrickson [30] exhibited that the total cost of the project as the expense to the owner of a constructed facility covers all initial capital costs and ongoing operation and maintenance costs. Each of these major categories of costs is composed of a range of cost components. The capital cost of a construction project includes costs related to the initial installation of the facility: land acquisition, including assembly, holding and enhancement, planning, feasibility studies, architectural and engineering design, construction, including materials, equipment and labor, construction field management, construction finance, insurance and taxes during construction. Working and maintenance costs over the life cycle of the project in subsequent years include the following expenditures: land rent, where appropriate, working personnel, maintenance and repair work and materials, regular upgrades, insurance and taxes, financing costs, services and other expenses of the owner [31].

\section{METHODOLOGY}

Project Costs includes all costs related to the purchase, leasing, design, engineering, development, licensing, insurance, funding (including closing costs and interest and interest rate hedge costs), building, installation, commissioning, testing and start-up, including all costs related to the project's equipment, supplies, spare parts and labor and all other costs incurred. Here, we collect cost sources and their variations estimated of new renewable energy project that presented in figure 1. In this study the cost was divided into different sources and each cost source was investigated separately. For this purpose brain storming with experts, contacts with operators, data from research papers and contact with suppliers were made to attempt to cover most cost sources along with their variations. The following proposed chart shows all possible costs of project stages that must be taken into consideration of renewable energy project stages as exhibited in figure 2. The model attempts to break the system cost into several equations each accounts for a source of cost. Finally all anticipated costs from various sources are integrated into the total cost equation (Equation 2) in results section. 

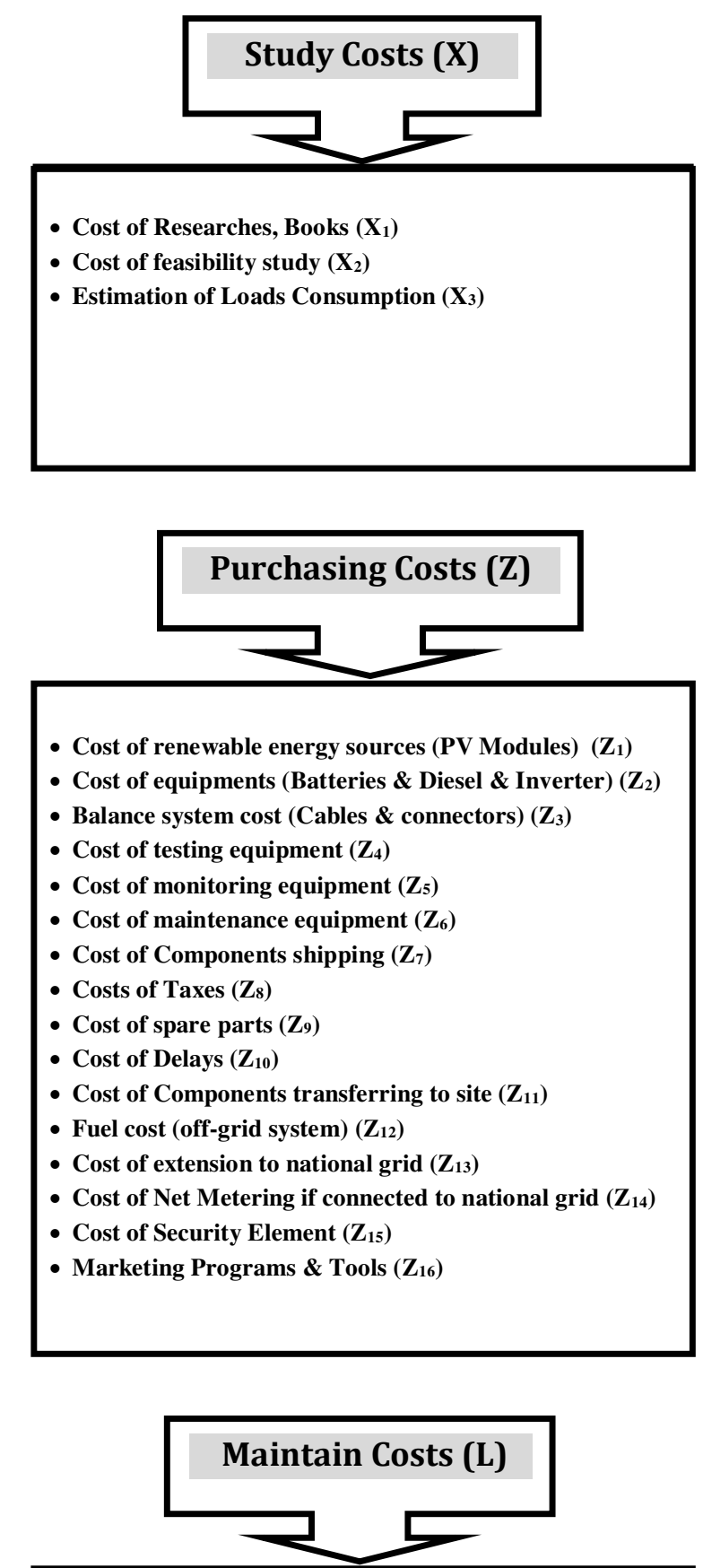

- Cost of planned maintenance $\left(L_{1}\right)$

- Maintenance Cost $\left(\mathrm{L}_{2}\right)$

- Cost of Delays $\left(\mathrm{L}_{3}\right)$

- Cost of repairs $\left(\mathrm{L}_{4}\right)$

- Cost of expansion in future $\left(L_{5}\right)$

- Risk \& Contingency Cost $\left(\mathrm{L}_{6}\right)$

- Shortage \& Shut Down Cost $\left(\mathrm{L}_{7}\right)$

- Stand by plan cost $\left(\mathrm{L}_{8}\right)$

- Cost of other company (Commission Company)(L9)

- Cost to security company $\left(\mathrm{L}_{10}\right)$

- Cost to market company ( $\left.\mathrm{L}_{11}\right)$

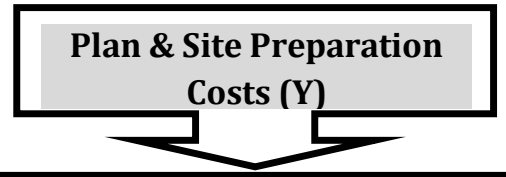

- Cost of traveling (if site very far) $\left(\mathrm{Y}_{1}\right)$

- Land Cost (Rent or .....)

- Site Visit: study location (latitude \& longitude), area sea level. $\left(Y_{2}\right)$

- Cost of design system (Drawing, Reports) $\left(\mathbf{Y}_{3}\right)$

- Cost of Software used $\left(\mathrm{Y}_{4}\right)$

- Sizing System Cost (estimation of all components, equipments materials and Labors) $\left(\mathbf{Y}_{5}\right)$

- Gantt Chart Cost (time Schedule) ( $\left.\mathbf{Y}_{6}\right)$

- Export to national grid if extra production $\left(\mathrm{Y}_{7}\right)$

- Investment and profit cost ( $\left.\mathrm{Y}_{8}\right)$

(Financial Parameters)

- Cost of inventory ( $\left.\mathbf{Y}_{9}\right)$

- Power quality level cost $\left(\mathrm{Y}_{10}\right)$

- Security Cost $\left(\mathbf{Y}_{11}\right)$

- Marketing Cost ( $\left.\mathbf{Y}_{12}\right)$

Fig. 1: Expected Cost Sources and Variations of New Renewable Energy Project

- Costs before system operating $\mathrm{C}_{1}=$ Study Costs $(\mathrm{X})+$ Plan \& Site Preparation Costs $(\mathrm{Y})+$ Purchasing Costs $(\mathrm{Z})$

- Costs after system operating $\mathrm{C}_{2}=$ Commissioning Costs $(\mathrm{K})+$ Maintain Costs $(\mathrm{L})$

- Total System Cost $=$ Costs before system operating $\mathrm{C}_{1}+$ Costs after system operating $\mathrm{C}_{2}$ 
It is clear from figure1; the cost before system operating is higher than cost after operating, it equal roughly 65\%: $35 \%$, respectively. So when we think to start the renewable energy system, we know previously that it will highly costly in beginning of project especially in first year due to purchasing and site preparation costs.

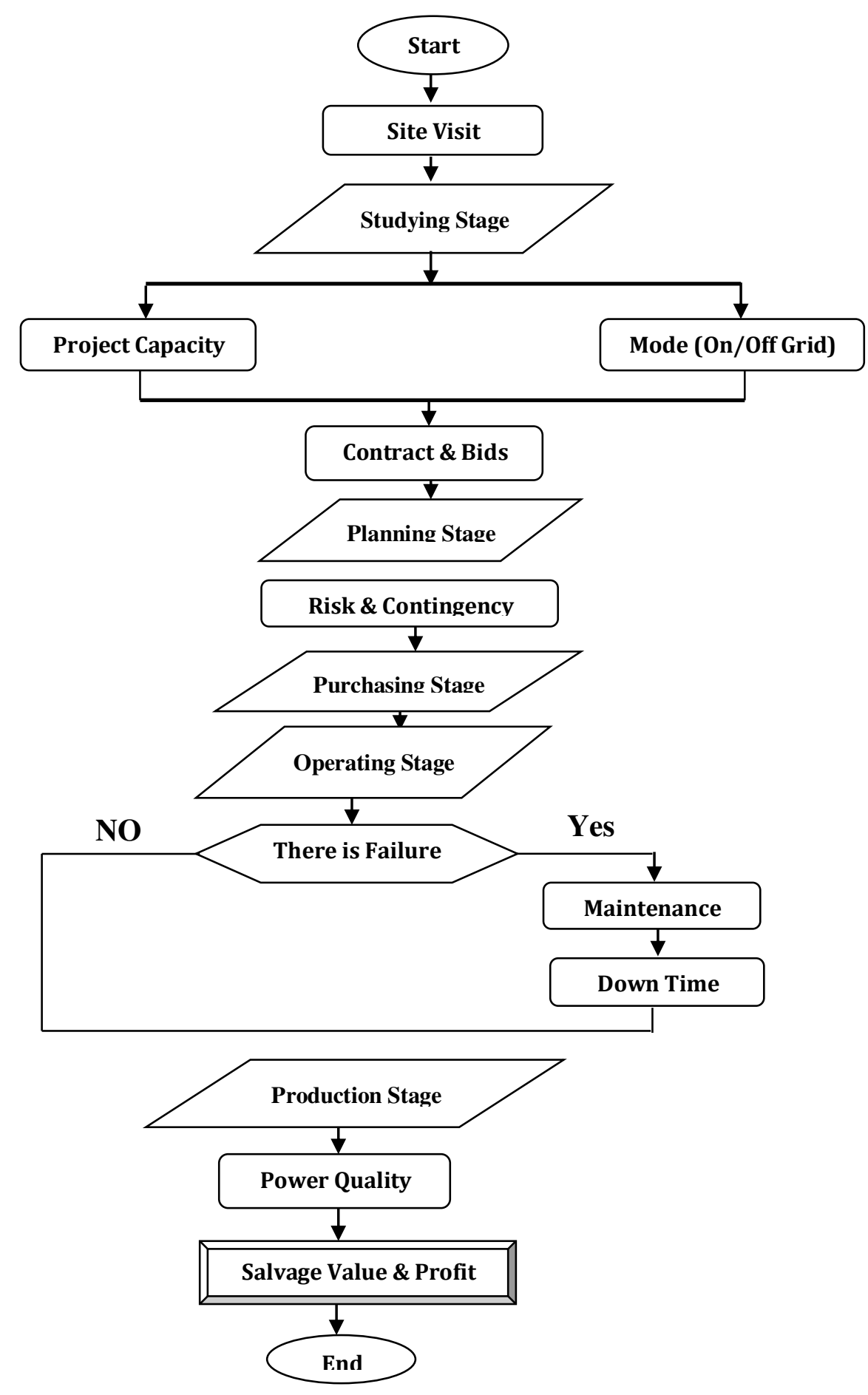

Fig.2: Flow Proposed Chart of Renewable Energy Project Stages Cost Items 


\section{RESULTS AND DISCUSSION}

\subsection{Cost Model Equations of Project Items}

Pervious costs of new renewable energy project (Fig.1) in simple items that appears in equation 2 in function of time and interest rate as following and the cost items are illustrated as following in table 1. Figure 3 illustrates simple proposed Cash Flow Diagram (CFD) of all pervious cost items. We assume the project lifetime is 25 year according to maximum lifetime component in solar energy project (PV Array).

$$
\begin{aligned}
& \mathrm{X}=\left[\left\{\mathrm{Y} \times \mathrm{V}_{1}\right\}+\mathrm{F}_{1}\right] \text { at }\left(\mathrm{T}_{\mathrm{i}} \& \mathrm{IR}_{\mathrm{Ti}}\right) \\
& \text { Where; } \quad \mathrm{X}: \text { Cost item } \\
& \mathrm{Y}: \text { Net Cost item } \\
& \mathrm{V}_{1} \text { : Variable factor related to country, location project } \\
& \mathrm{F}_{1}: \text { Fixed Cost related to item } \\
& \text { } \mathrm{T}_{\mathrm{i}} \text { : Time related to item (i) } \\
& \text { IR: interest Rate at } \mathrm{T}_{\mathrm{i}}
\end{aligned}
$$

\begin{tabular}{|c|c|c|c|}
\hline Cost Item & Expression & Time (Ti) & $\begin{array}{l}\text { Interest } \\
\text { Rate (IR) } \\
(\%)\end{array}$ \\
\hline $\begin{array}{l}\text { Components Purchasing Cost } \\
\left(\mathrm{X}_{1}\right)\end{array}$ & $\mathrm{X}_{1}=\left[\left(\mathrm{Y}_{1} \times\right.\right.$ customs $)+($ shipping + packing cost $\left.)\right]$ & 0 & 0 \\
\hline $\begin{array}{l}\text { Other Purchasing Cost }\left(\mathrm{X}_{2}\right) \\
\text { (Replacement \& security) }\end{array}$ & $\mathrm{X}_{2}=\left[\left(\mathrm{Y}_{2} \times\right.\right.$ entrance fee $)+($ transportation cost $\left.)\right]$ & $\begin{array}{l}\text { - }(4,8,12,16,20,24) \\
\text { for Batteries } \\
\text { - }(15) \text { for inverter } \\
\text { - }(10,20) \text { for Diesel }\end{array}$ & $\begin{array}{c}(10 \& 15) \\
\text { at } \mathrm{T}_{\mathrm{i}}\end{array}$ \\
\hline Delay Cost $\left(\mathrm{X}_{3}\right)$ & $\mathrm{X}_{3}=\left[\left(\mathrm{Y}_{3} \times\right.\right.$ taxes fee $)+($ transportation cost $\left.)\right]$ & 0 & 0 \\
\hline Net Metering Cost $\left(\mathrm{X}_{4}\right)$ & $\mathrm{X}_{4}=\left[\left(\mathrm{Y}_{4} \times\right.\right.$ license $)+($ transportation cost $\left.)\right]$ & 25 & 0 \\
\hline Inventory, Land Cost $\left(\mathrm{X}_{5}\right)$ & $\mathrm{X}_{5}=\left[\left(\mathrm{Y}_{5} \times\right.\right.$ taxes $)+($ documents cost $\left.)\right]$ & $(5,10,15,20)$ & 10 at $\mathrm{T}_{\mathrm{i}}$ \\
\hline Heavy Equipment Cost $\left(\mathrm{X}_{6}\right)$ & $X_{6}=\left[\left(Y_{6} \times\right.\right.$ entrance fee $)+($ transportation cost $\left.)\right]$ & 0 & 0 \\
\hline Employee, Security Cost $\left(\mathrm{X}_{7}\right)$ & $\mathrm{X}_{7}=\left[\left(\mathrm{Y}_{7} \times\right.\right.$ Insurance $)+($ transportation cost $\left.)\right]$ & $(5,10,15,20)$ & 10 at $\mathrm{T}_{\mathrm{i}}$ \\
\hline Consultant Cost $\left(\mathrm{X}_{8}\right)$ & $\mathrm{X}_{8}=\left[\left(\mathrm{Y}_{8} \times\right.\right.$ documents $)+($ transportation cost $\left.)\right]$ & $(5,10,15,20)$ & 15 at $\mathrm{T}_{\mathrm{i}}$ \\
\hline Infrastructure Cost $\left(\mathrm{X}_{9}\right)$ & $\mathrm{X}_{9}=\left[\left(\mathrm{Y}_{9} \times\right.\right.$ license $)+($ labor cost $\left.)\right]$ & 0 & 0 \\
\hline Labor Services Cost $\left(\mathrm{X}_{10}\right)$ & $\mathrm{X}_{10}=\left[\left(\mathrm{Y}_{10} \times\right.\right.$ license $)+($ Labor, things used cost $\left.)\right]$ & $(5,10,15,20)$ & 10 at $\mathrm{T}_{\mathrm{i}}$ \\
\hline Planning Study Cost $\left(\mathrm{X}_{11}\right)$ & $\mathrm{X}_{11}=\left[\left(\mathrm{Y}_{11}\right)+(\right.$ reports $\left.)\right]$ & 0 & 0 \\
\hline Design, Drawing Cost $\left(\mathrm{X}_{12}\right)$ & $X_{12}=\left[\left(Y_{12}\right)+(\right.$ Software, Paper, CD .. Cost $\left.)\right]$ & 0 & 0 \\
\hline Downtime Cost $\left(\mathrm{X}_{13)}\right.$ & $\mathrm{X}_{13}=\left[\left(\mathrm{Y}_{13}\right)+(\right.$ instrument cost $\left.)\right]$ & $\begin{array}{l}\operatorname{Ti}(\mathrm{x} 1, \mathrm{x} 14) \\
\text { Depend on failure or } \\
\text { maintenance time }\end{array}$ & 10 at $\mathrm{T}_{\mathrm{i}}$ \\
\hline Maintenance, Safety Cost $\left(\mathrm{X}_{14)}\right.$ & $\mathrm{X}_{14}=\left[\left(\mathrm{Y}_{14}\right)+(\right.$ Instrument, labor Cost $\left.)\right]$ & $(4,8,12,16,20,24)$ & 10 at $\mathrm{T}_{\mathrm{i}}$ \\
\hline Pollution Off-Grid Cost:( $\left.\mathrm{X}_{15}\right)$ & $X_{15}=\left[\left(Y_{15} \times \mathrm{kg}\right.\right.$ of $\mathrm{CO}_{2}$ cost $)+($ reports cost $\left.)\right]$ & $(1,2,3,4 \ldots . .25)$ & 15 at $\mathrm{T}_{\mathrm{i}}$ \\
\hline $\begin{array}{l}\text { Risk Cost: }\left(\mathrm{X}_{16}\right) \\
\text { (electricity generated) }\end{array}$ & $\begin{aligned} \mathrm{X}_{16}= & {\left[\left(\mathrm{Y}_{16} \times \text { interest rate, bank issue }\right)\right.} \\
& +(\text { Power quality cost })]\end{aligned}$ & 0 & 0 \\
\hline Security Cost: $\left(\mathrm{X}_{17}\right)$ & $\mathrm{X}_{17}=\left[\left(\mathrm{Y}_{17} \times\right.\right.$ Labor Cost $)+($ Transportation Cost $\left.)\right]$ & $(0,1,2,3,4 \ldots .25)$ & 10 at $\mathrm{T}_{\mathrm{i}}$ \\
\hline Marketing Cost $\left(\mathrm{X}_{18}\right)$ & $\begin{aligned} \mathrm{X}_{18}= & {\left[\left(\mathrm{Y}_{18} \times \text { Employee cost }\right)\right.} \\
& +(\text { Marketing Tools \& Programs })]\end{aligned}$ & 25 & 10 \\
\hline Extension Grid Cost: $\left(\mathrm{X}_{19}\right)$ & $\mathrm{X}_{19}=\left[\left(\mathrm{Y}_{19} \times\right.\right.$ cables cost $)+($ transportation Cost $\left.)\right]$ & 25 & 0 \\
\hline
\end{tabular}

Table 1: Cost items of New Renewable Energy Project 


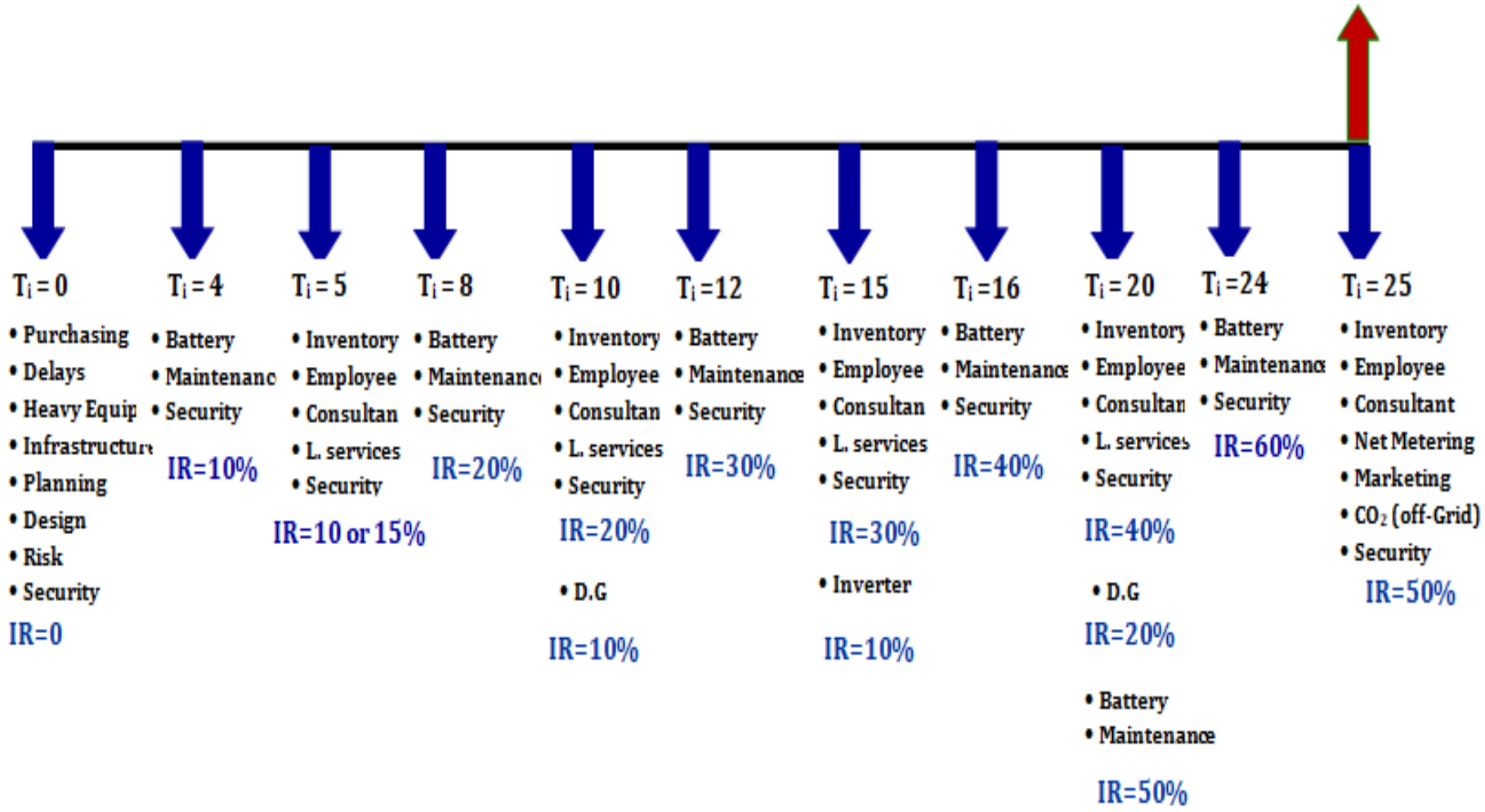

Note: Shortage \& Downtime Cost depends on Failure Type and Time

Fig.3: Proposed Cash Flow Diagram of Renewable Energy System Costs

From table 1 and figure 3; it could be seen that the high cost in replacement stage and land or inventory. The marketing and maintenance costs also have the high percentage of project costs along the project life time. Risk cost must be taken into consideration of overall project cost. The salvage value cost appears in the end of project lifetime as well as $\mathrm{CO}_{2}$ cost saving will be calculated in this time to see how this renewable energy project participate in eliminating of emissions in case of isolated system.

\subsection{Total Renewable Energy Project Cost Model Expression}

Project Cost is the overall expenditure required to complete the project or job consisting of direct and indirect costs. The Project Costs are any expenses incurred or estimated to be incurred, or monetary obligations incurred or estimated to be incurred to complete the project listed in a project baseline. Full cost of the project is the cost of all project phases including the environment, design, right-of-way, utilities, and construction. Cost estimating involves activities to determine the cost of an initiative or project. The accuracy of the estimate can vary, depending on the need and the type of estimate done. Generally, at the preliminary stages of a project, rough estimates are provided. Many times, a rough estimate is referred to as a ballpark figure and just provides a starting point to determine project costs. RES inputs and outputs cost items scheme is shown in figure 4. 


\section{Inputs}

$\underline{\text { Process }}$

$\underline{\text { Outputs }}$

- Study Cost

-Planning Cost

-Purchasing Cost

- Other Cost

\section{Operation \& Executive \\ Maintenance Cost}

- Total Cost (TC)

- Cost of Energy (COE)

Fig.4: Renewable Energy System Inputs \& Outputs Cost Items

This is an important value, because it is used to measure the system's two main economic merit figures: the Total Cost of Photo-Voltaic System (TCPVS) and the cost of energy (COE) as shown in figure 1 . The total renewable energy cost could be derived from previous costs as following in Equations 3, 4:

$$
\begin{aligned}
& (\text { TCPVS })=\{\text { Study Cost }(\mathrm{X})+\text { Planning Cost }(\mathrm{Y})+\text { Purchasing Cost }(\mathrm{Z}) \\
& + \text { Executive \& Operation Cost }(\mathrm{K})+\text { Others Cost }(\mathrm{L})\}
\end{aligned}
$$

$(\mathrm{TCPVS})=\sum_{i=1}^{n} X i$, at Ti\&IR, n: Project Life Time (25 year)

This equation 4 should account for most cost sources. It especially accounts for variations that would be anticipated in developing countries. From pervious cost items in table 1 and equations $2 \& 3 \& 4$, we can put the costs of new solar energy project as following in equation $(5,6)$ :

For estimation of $1 \mathrm{~kW}$; total cost of PV system is

$$
1 \mathrm{~kW} \text { cost }=\frac{\text { T.C }(\mathrm{PVS})}{\text { Capacity System }(\text { Load of } \mathrm{kW})}
$$

Note: Roughly $1 \mathrm{~kW}$ requires $10 \mathrm{~m}^{2}$ area

For estimation of $1 \mathrm{kWh}$ cost; (COE) of PV system is:

Hence the levelized cost of energy is the average cost per kilowatt-hour of the system's usable electrical energy as following in equation 6:

$$
\operatorname{COE}(\text { Cost of Energy })=\frac{\text { T.C annual }}{\{\text { Eload }+ \text { Egrid }\}}
$$

Since; $\mathrm{E}_{\mathrm{Load}}$ and Egrid are the total amounts of electrical load that the system serves per year and energy sold to the grid per year.

For example; If PV system is constructed in Egyptian site, since capacity system is $100 \mathrm{~kW}$ and the costs of whole project are stated as following: 
I) On-Grid Mode: as shown in figure 5

- Study cost, $\mathrm{X}=120,000$ L.E

- Planning Cost, Y=200,000 L.E

- Purchasing cost, $\mathrm{Z}=500,000$ L.E

- Operation \& Maintenance cost, K= 300,000 L.E

- Other cost, $\mathrm{L}=80,000$

Total Cost $=\{120,000+200,000+500,000+300,000+80,000\}=1,200,000$ L.E

$1 \mathrm{~kW}$ cost $=\left\{\frac{1,200,000}{100}\right\}=12,000$ L.E

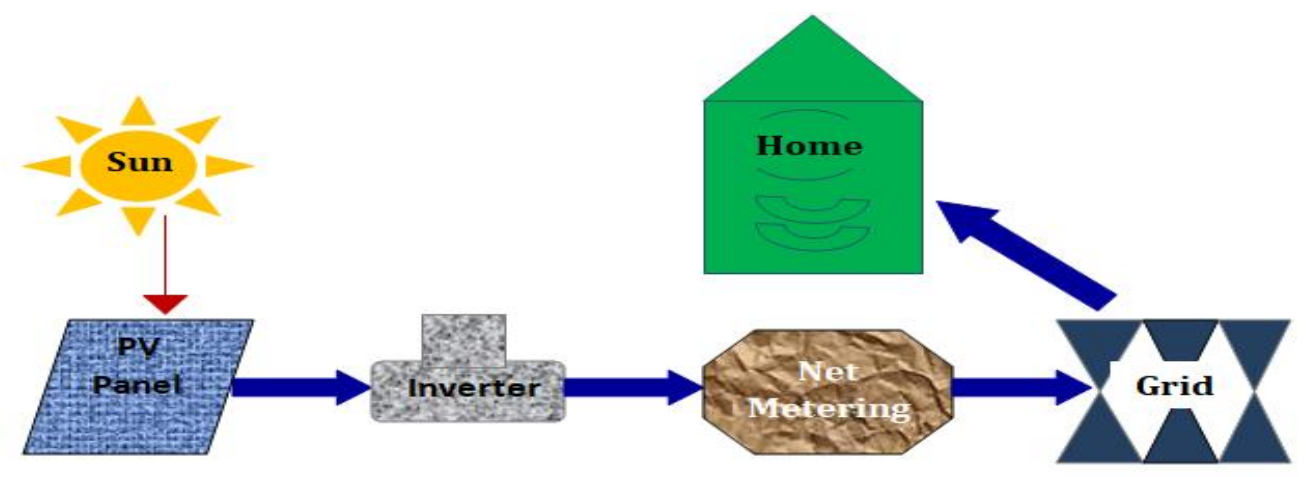

Fig.5: On- Grid PV System Scheme

II) Off-Grid Mode: as exhibited in figure 6

- Study cost, $X=120,000$ L.E

- Planning Cost, $Y=200,000$ L.E

- Purchasing cost, $\mathrm{Z}=700,000$ L.E

- Operation \& Maintenance cost, K= 300,000 L.E

- Other cost, $\mathrm{L}=100,000$

Total Cost $=\{120,000+200,000+700,000+300,000+100,000\}=1,420,000$ L.E

$1 \mathrm{~kW}$ cost $=\left\{\frac{1,420,000}{100}\right\}=14,200 \mathrm{~L} \cdot \mathrm{E}$

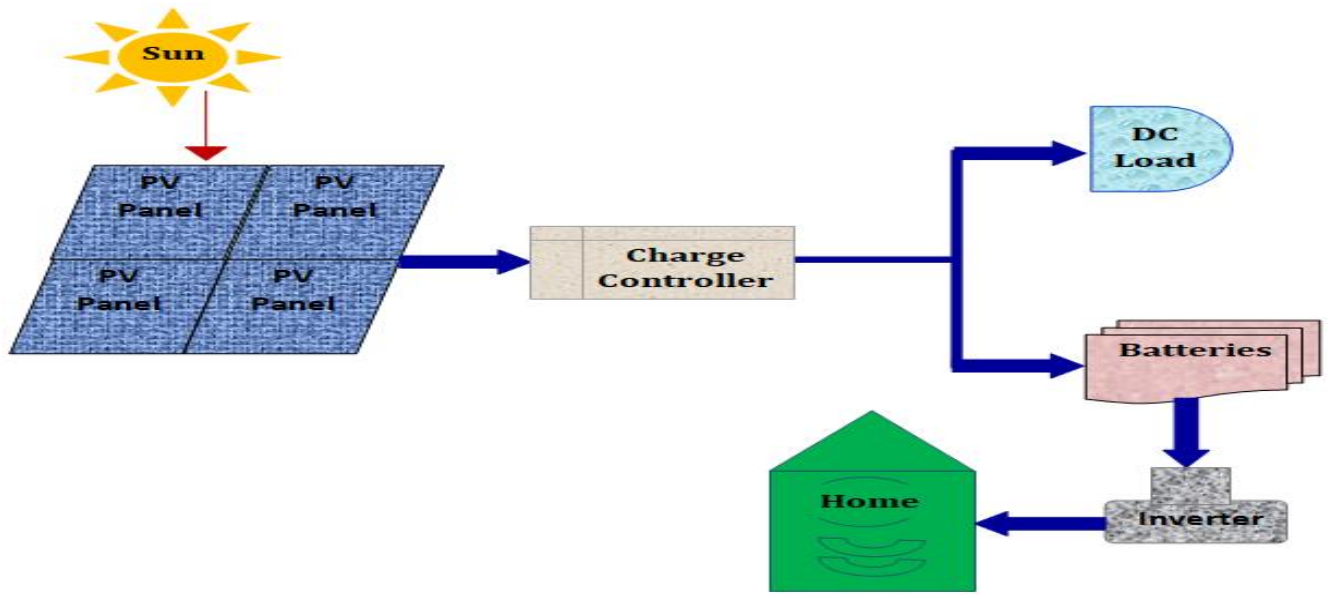

Fig.6: Isolated/Off-Grid PV System Scheme

From pervious figure $(5,6)$; it is clear off-grid system cost is higher than on-grid system and also cost of electricity generated and maintenance processing is very difficult for isolated system. 


\subsection{Renewable Energy Project Risks \& Successful Factors:}

This section presents risks types of renewable energy project and successful factor of this energy project.

\subsubsection{Renewable project risks types:}

The renewable energy industry is a complex dynamic system with complex relationships between its subsystems and components, so it can be viewed as a closed and complicated selfadaptive system, and system theory could be used to evaluate its risks. Based on the feedback theory of system dynamics, the renewable energy industry risk model for system dynamics feedback was developed based on its own characteristics, development status, market economy principles and industry regulator. There are various types of risks affecting the accomplishments of renewable energy projects as follows, and percentages of these risks are shown in Figure 7 that specific technical risks are prioritized in project risk analysis as follows:

- Technical Risk: strategic/business risk, insufficient management, technology and innovation risk, transport/construction, reserve risks, completion risks, commission delayed risk, traditional risk and regulatory risks.

- Commercial Risk: financial risk, operation/ maintenance, market risk, supply risks, spare parts availability, economic risks, credit risk, liquidity risk.

- Others Risk: country risk, legal risk, site resources risks (radiation), social risk and insurance coverage.

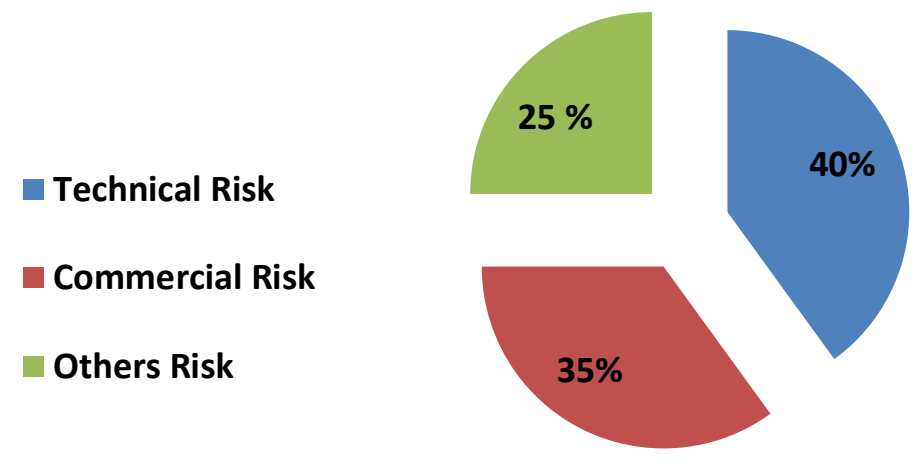

Fig.7: Percentages of Risks Classification of Renewable Energy System

From figure 7; it is clear that technical risk has the most percentage of project energy risks.

\subsubsection{Renewable project success factors:}

- Communication factors: leadership, stability, flexibility

- Technical: integration task, quality testing, technology support

- Organization: top management support, organization politics, financial support

- Team: teamwork, team competence, team empowerment

-Environment: domestic interest rate, domestic capital market, legal environment 


\section{CONCLUSIONS}

In this research a system of renewable energy systems cost equations has been presented and check list of new solar energy system is presented. The developed system of cost equations has the capacity to anticipate most sources of renewable energy systems costs and their variations. Total costs of new RES project are illustrated and collecting them in general equation. Two outcomes terms have been concluded to Total Cost of Photo-Voltaic System (TCPVS) and Cost of Energy (COE) that has a vital role of economic performance of any renewable energy system. Cost of electricity either on-grid or off-grid system also calculated. The result showed that the high cost in replacement stage and land or inventory. The marketing and maintenance costs have the high percentage of project costs along the project life time. The salvage value cost appears in the end of project lifetime in addition to $\mathrm{CO}_{2}$ cost saving are taken into consideration of renewable energy project in eliminating of emissions in case of isolated system. Also, results illustrated that cost of off-grid system is higher than on-grid system due to high cost of batteries as well as maintenance process of isolated system is very costly. So, it is better to install off-grid system in remote or isolated area or back-up system in case of electricity shortage. All successful and risk factors of new renewable energy system are exhibited in this study; the technical risk is highest percentage of project risks.

\section{CONFLICT OF INTEREST}

The authors do not report conflicts of interest.

\section{REFERENCES}

[1] J. D. Sachs, W. T. Woo, N. Yoshino, and F. Taghizadeh-Hesary, "Importance of Green Finance for Achieving Sustainable Development Goals and Energy Security," Handb. Green Financ., pp. 3-12, 2019, doi: 10.1007/978-981-13-0227-5_13.

[2] B. Steffen, "The importance of project finance for renewable energy projects," Energy Econ., vol. 69, pp. 280-294, 2018, doi: 10.1016/j.eneco.2017.11.006.

[3] J. D. Sachs and W. Thye, Handbook of Green Finance. 2019.

[4] C. W. Lee and J. Zhong, "Financing and risk management of renewable energy projects with a hybrid bond," Renew. Energy, vol. 75, pp. 779-787, 2015, doi: 10.1016/j.renene.2014.10.052.

[5] A. Ebers and N. Hampl, "Community Financing of Renewable Energy Projects in the Age of Low and Negative Interest Rates in Austria and Switzerland," 2016.

[6] Z. S. and Y. C. Zhai Q, Alberts S, Cao H, "Strength Analysis of International Feed-in Tariff Promotion of Clean Energy Applications for Greenhouse Gas Emission Mitigation," Sustain. Syst. Technol. (ISSST), 2010.

[7] H. Khatib, "Economics of new renewables: is there viable energy at the end of the renewables tunnel?," Econ. Eval. Proj. Electr. Supply Ind., pp. 179-195, 2014, doi: 10.1049/pbpo070e_ch12.

[8] and M. E. Wüstenhagen R., "Strategic Choices for Renewable Energy Investment: Conceptual Frame Work and Opportunities for Further Research,” Energy Policy, vol. 40, 2012.

[9] and W. R. Helms T., Salm S., "Investor Specific Cost of Capital and Renewable Energy Investment Decisions," Renew. Energy Financ. Imp. Coll. Press, 2015.

[10] S. Salm, S. L. Hille, and R. Wüstenhagen, "What are retail investors' risk-return preferences towards renewable energy projects? A choice experiment in Germany," 
Energy Policy, vol. 97, pp. 310-320, 2016, doi: 10.1016/j.enpol.2016.07.042.

[11] IRENA, Unlocking Renewable Energy Investment : the Role of Risk Mitigation. 2016.

[12] B. Sweerts, F. D. Longa, and B. van der Zwaan, "Financial de-risking to unlock Africa's renewable energy potential," Renew. Sustain. Energy Rev., vol. 102, no. December 2018, pp. 75-82, 2019, doi: 10.1016/j.rser.2018.11.039.

[13] J. C. Ketterer, "The impact of wind power generation on the electricity price in Germany," Energy Econ., vol. 44, 2014.

[14] S. A. A. Shah and Y. A. Solangi, "A sustainable solution for electricity crisis in Pakistan: opportunities, barriers, and policy implications for 100\% renewable energy," Environ. Sci. Pollut. Res., vol. 26, no. 29, pp. 29687-29703, 2019, doi: 10.1007/s11356-019-06102-0.

[15] M. Hain, H. Schermeyer, M. Uhrig-Homburg, and W. Fichtner, "Managing renewable energy production risk," J. Bank. Financ., vol. 97, pp. 1-19, 2018, doi: 10.1016/j.jbankfin.2018.09.001.

[16] R. Markets, www.econstor.eu. 2017.

[17] A. Shimbar and S. B. Ebrahimi, "Political risk and valuation of renewable energy investments in developing countries," Renew. Energy, vol. 145, pp. 1325-1333, 2020, doi: 10.1016/j.renene.2019.06.055.

[18] G. Bekaert, C. R. Harvey, C. T. Lundblad, and S. Siegel, "Political risk spreads," J. Int. Bus. Stud., vol. 45, no. 4, pp. 471-493, 2014, doi: 10.1057/jibs.2014.4.

[19] "THE POLITICS OF RENEWABLE ENERGY : THE CASE OF LOCAL- Presented to the Faculty of San Diego State University In Partial Fulfillment of the Requirements for the Degree Master of Arts in Political Science by Mohammad Ali Zarabi Summer 2019," 2019.

[20] N. Gatzert and T. Kosub, "Risks and risk management of renewable energy projects: The case of onshore and offshore wind parks," Renew. Sustain. Energy Rev., vol. 60, pp. 982998, 2016, doi: 10.1016/j.rser.2016.01.103.

[21] Germán MartínezMontesaEnrique PradosMartín, "Profitability of wind energy: Shortterm risk factors and possible improvements," Renew. Sustain. Energy Rev., vol. 11, 2007.

[22] J. Barroco and M. Herrera, "Clearing barriers to project finance for renewable energy in developing countries: A Philippines case study," Energy Policy, vol. 135, no. September, p. 111008, 2019, doi: 10.1016/j.enpol.2019.111008.

[23] R. Pacudan, "Implications of applying solar industry best practice resource estimation on project financing," Energy Policy, vol. 95, pp. 489-497, 2016, doi: 10.1016/j.enpol.2016.02.021.

[24] X. Liu and M. Zeng, "Renewable energy investment risk evaluation model based on system dynamics,” Renew. Sustain. Energy Rev., vol. 73, no. November 2016, pp. 782788, 2017, doi: 10.1016/j.rser.2017.02.019.

[25] A. Jahani, P. Mohammadi, and H. Mashreghi, "Effect of Risk on Evaluating the Financing Methods of New Technology-Based Firms," Int. J. Ind. Eng. Prod. Res., vol. 29, no. 2, pp. 133-146, 2018, doi: 10.22068/ijiepr.29.2.133.

[26] Ecofys, Eclareon, Fraunhofer ISI, EPU-NTUA, LEI, and TU Wien, "The impact of risks in renewable investments and the role of smart policies," no. February, 2016.

[27] R. Maqbool and Y. Sudong, "Critical success factors for renewable energy projects; empirical evidence from Pakistan,” J. Clean. Prod., vol. 195, pp. 991-1002, 2018, doi: 10.1016/j.jclepro.2018.05.274.

[28] K. K. (ed. . Humphreys, Project and Cost Engineers' Handbook, 4th ed. (sponsored by American Association of Cost Engineers), 2nd Ed., Marcel Dekker, Inc., New York, 2012., 2012.

[29] Mauricio Torres Consulo; André Luiz Veiga Gimenes ; Stefania Gomes Relva ; Miguel Edgar Morales Udaeta, "Basics on Energy Economics of Renewable Power Generation 
Projects: A focus on utility-scale PV plants inclusion on national grid," 2019 10th Int. Renew. Energy Congr., 2019.

[30] T. A. Chris Hendrickson, Project Management for Construction: Fundamental Concepts for Owners, Engineers, Architects, and Builders (PRENTICE-HALL INTERNATIONAL SERIES IN CIVIL ENGINEERING AND ENGINEERING MECHANICS). 2008.

[31] Alejandro Ciruelos Alonso, "Project Finance and the Supply of Credit from Commercial Banks,” Renew. Energy Financ., 2015. 

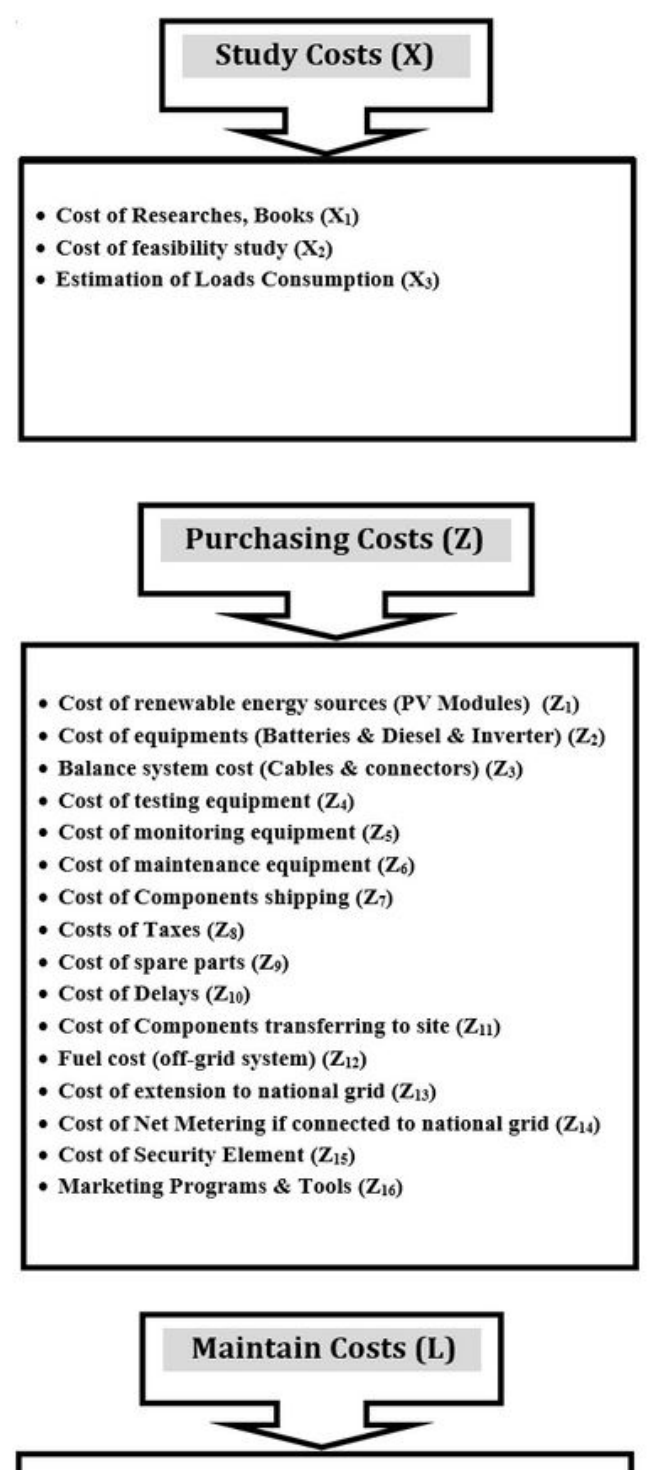

- Cost of planned maintenance $\left(L_{1}\right)$

- Maintenance Cost $\left(\mathrm{L}_{2}\right)$

- Cost of Delays $\left(\mathrm{L}_{3}\right)$

- Cost of repairs $\left(\mathrm{L}_{4}\right)$

- Cost of expansion in future $\left(\mathrm{L}_{5}\right)$

- Risk \& Contingency Cost $\left(\mathrm{L}_{6}\right)$

- Shortage \& Shut Down Cost $\left(\mathrm{L}_{7}\right)$

- Stand by plan cost $\left(\mathrm{L}_{s}\right)$

- Cost of other company (Commission Company) $\left(\mathrm{L}_{9}\right)$

- Cost to security company $\left(\mathrm{L}_{10}\right)$

- Cost to market company $\left(\mathrm{L}_{11}\right)$
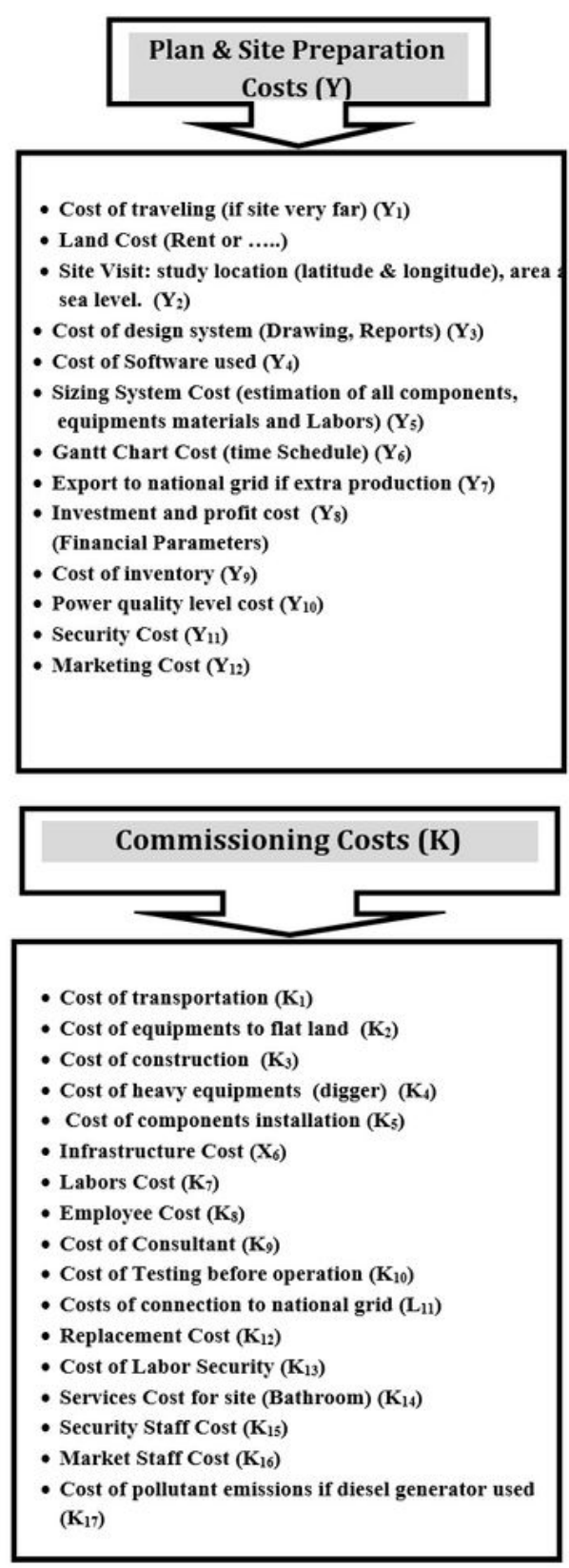

\section{Figure 1}




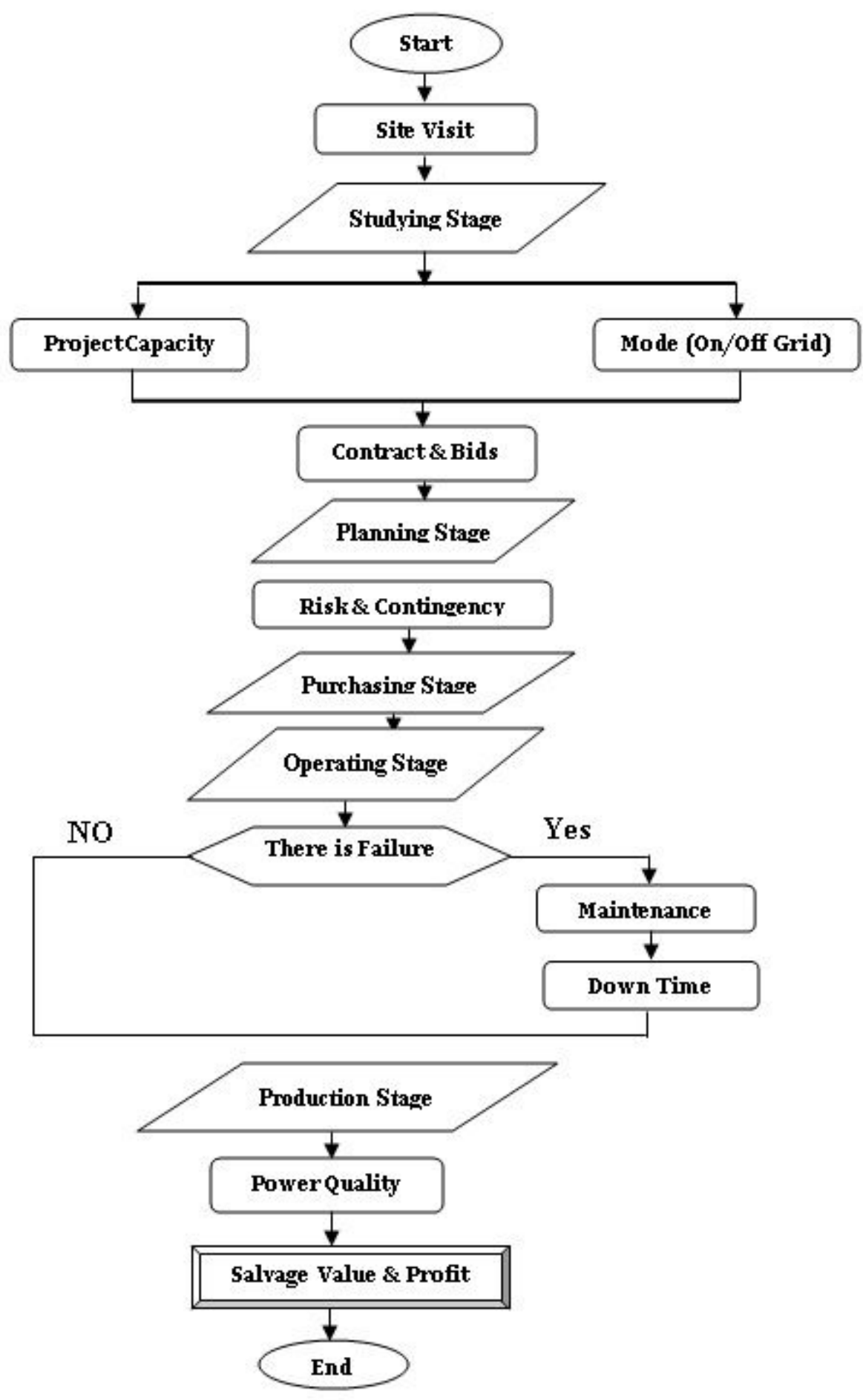

Figure 2

Flow Proposed Chart of Renewable Energy Project Stages Cost Items 


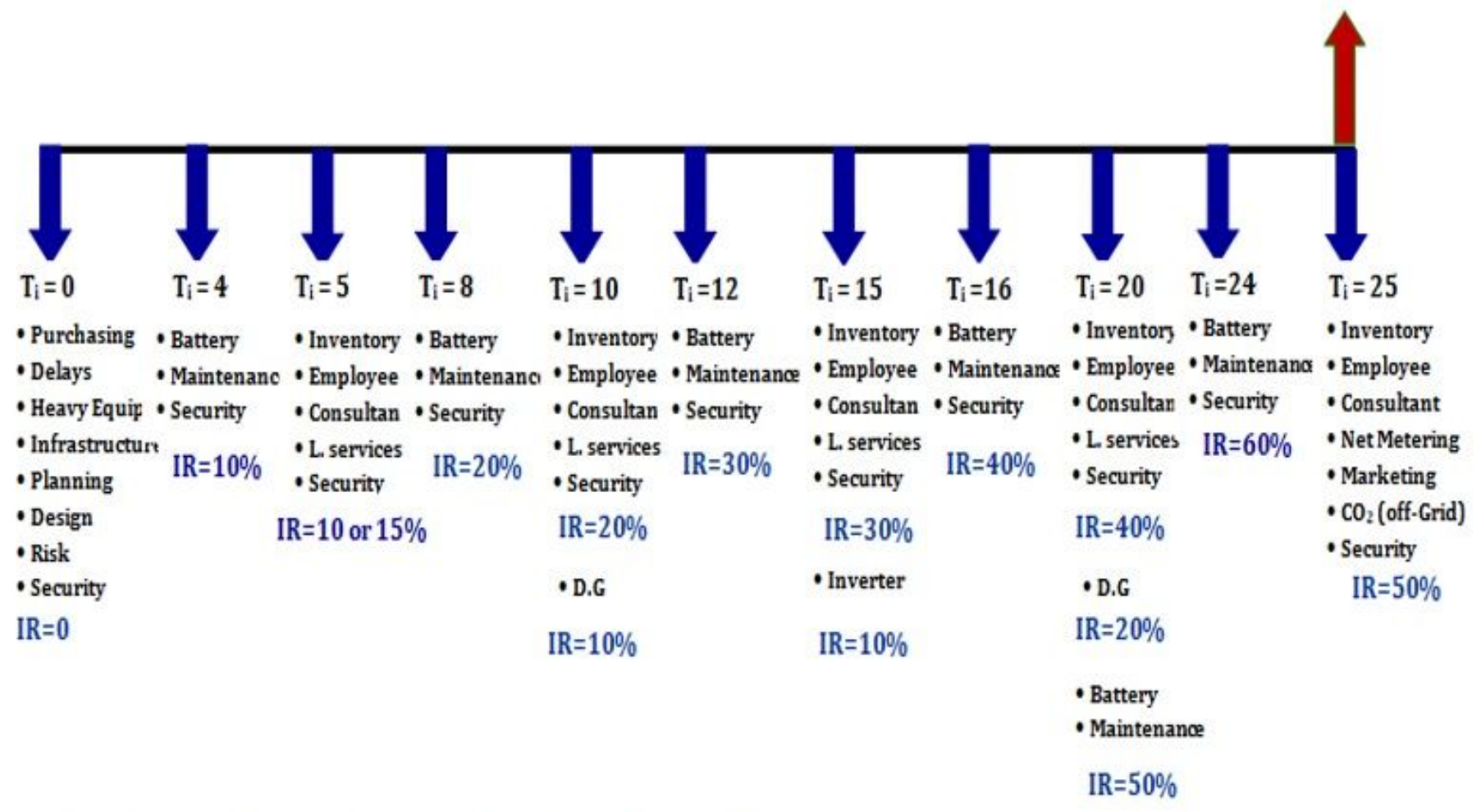

Note: Shortage \& Downtime Cost depends on Failure Type and Time

Figure 3

Proposed Cash Flow Diagram of Renewable Energy System Costs

\section{Inputs}

- Study Cost

- Planning Cost

-Purchasing Cost

- Other Cost $\underline{\text { Process }}$

$\underline{\text { Outputs }}$

- Total Cost (TC)

Operation \& Executive

Maintenance Cost

- Cost of Energy (COE)

\section{Figure 4}




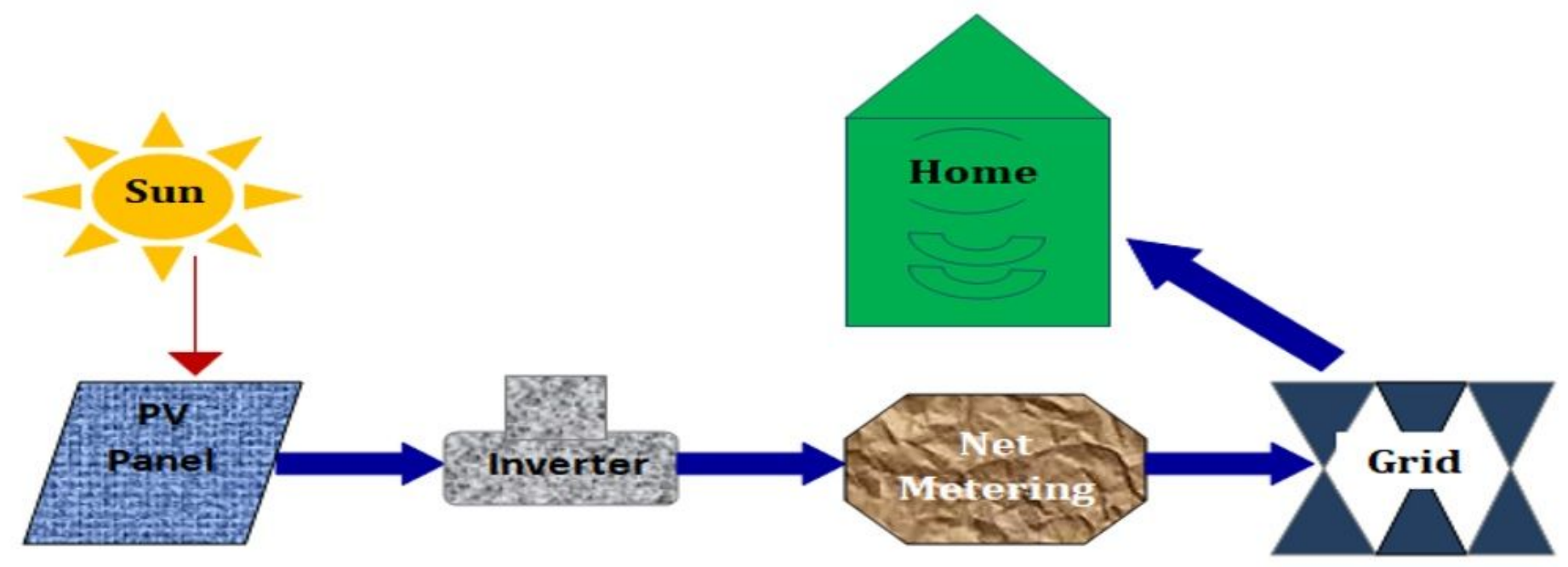

Figure 5

On- Grid PV System Scheme

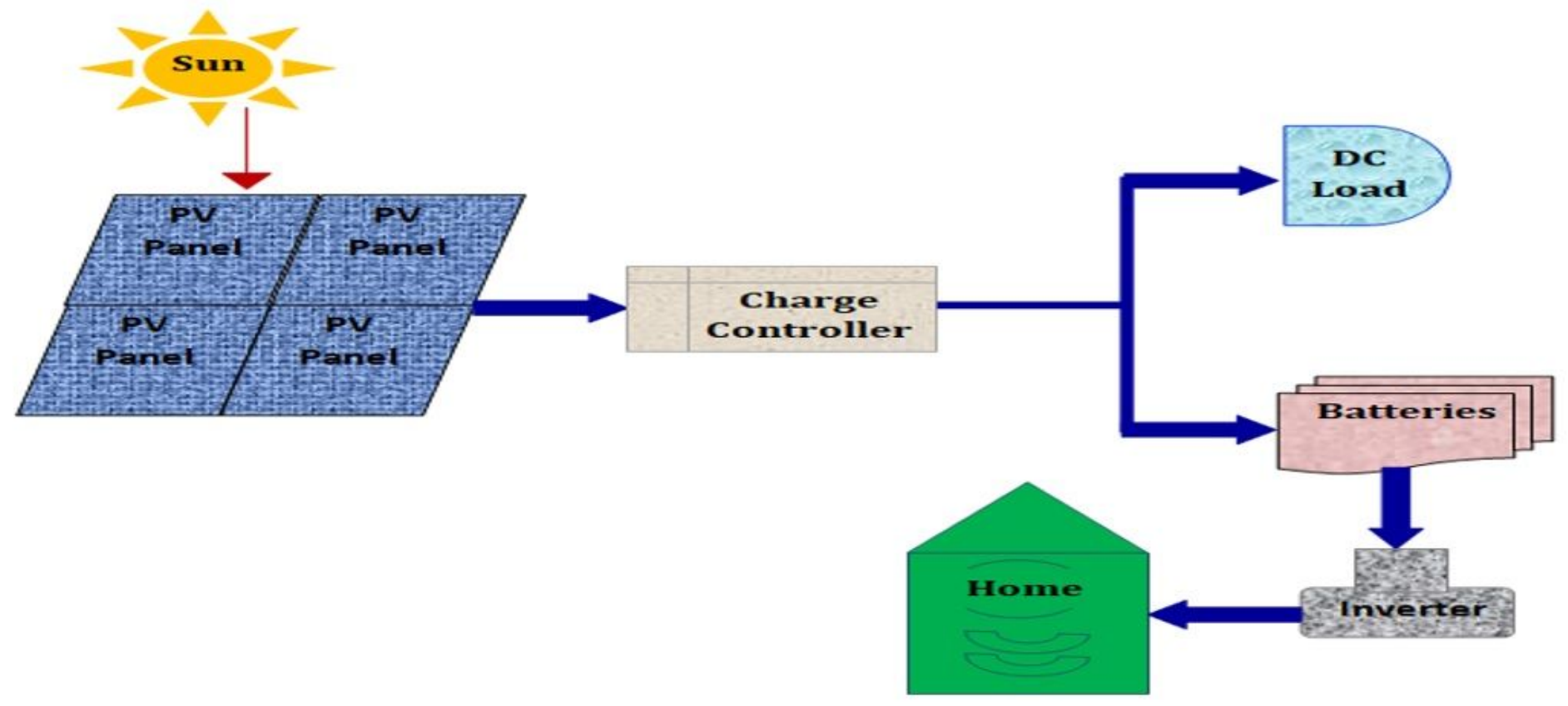

Figure 6

Isolated/Off-Grid PV System Scheme 


\section{Technical Risk}
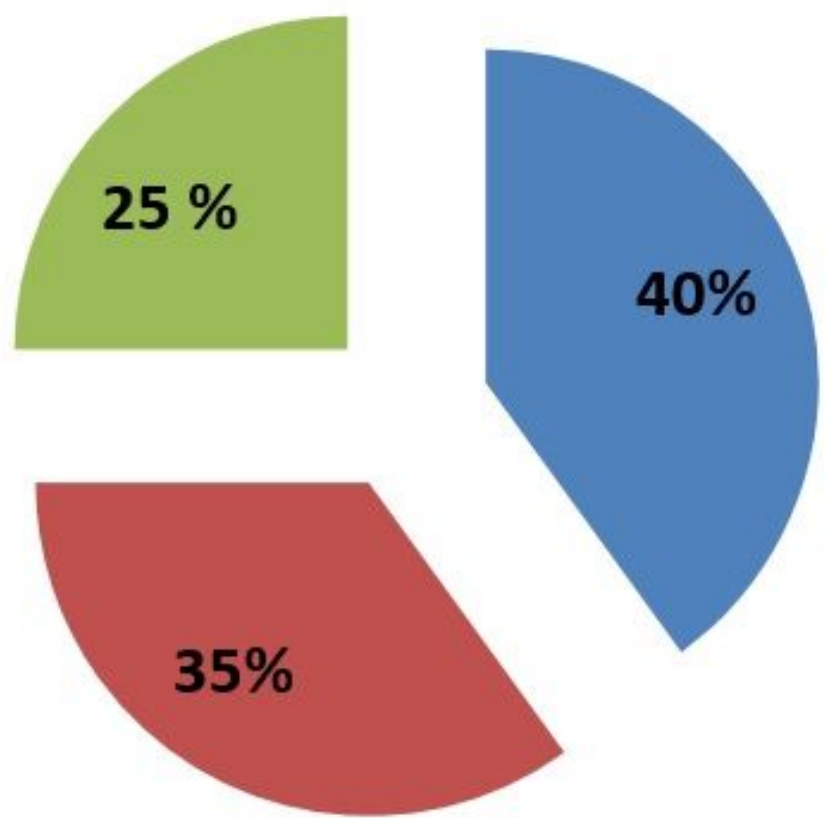

Figure 7

Percentages of Risks Classification of Renewable Energy System 